\title{
A Partial Budget Model to Estimate Economic Benefits of Lactational Treatment of Subclinical Staphylococcus aureus Mastitis
}

\author{
J. M. Swinkels, ${ }^{1}$ H. Hogeveen, ${ }^{2}$ and R. N. Zadoks ${ }^{3}$ \\ ${ }^{1}$ Innovet Bovine Herd Health Consultancy, Noordbeemster, 1463 PJ, The Netherlands \\ ${ }^{2}$ Department of Farm Animal Health, Utrecht University, PO Box 80851, 3508 TD Utrecht, The Netherlands \\ ${ }^{3}$ Quality Milk Production Services, Cornell University, Ithaca, NY, 14850-1263
}

\begin{abstract}
Subclinical Staphylococcus aureus mastitis is rarely treated during lactation because it is widely believed to be uneconomical, although there are no economic studies that support this view. Partial budgeting was used to develop a deterministic simulation model to estimate the net cost or benefit of antibiotic treatment of subclinical S. aureus mastitis during lactation. Direct and indirect effects of treatment were taken into account, including prevention of clinical flare-ups and contagious transmission. Input variables were based on literature and on 2003-2004 prices in the Netherlands. When contagious transmission of $S$. aureus was likely (reproductive ratio $\mathrm{R}=5.3$ ), 3 - and 8-d treatments resulted in an average net profit of $€ 95.62$ and $€ 142.42$, respectively, compared with no treatment. When the probability of $S$. aureus transmission was low $(R=0.32)$, the average economic benefit of 3- or 8-d treatment was $-€ 21.12$ and $-€ 57.70$, respectively. On low-transmission farms, 3-d treatment was profitable when the appropriate cows were selected for treatment using known risk factors for cure. Sensitivity analysis showed that the 6 most influential input variables in the model were chance of bacteriological cure, R, probability of culling, retention pay-off, and cost of antibiotics and bacterial culture. Although the economic outcome of lactational treatment of subclinical $S$. aureus mastitis is highly herd-, cow-, and strain-dependent, treatment is economically justified in many situations.
\end{abstract}

(Key words: Staphylococcus aureus, treatment, economic, partial budget)

Abbreviation key: BMSCC = bulk milk somatic cell count, $\mathbf{P C}=$ probability of cure, $\mathbf{P R}=$ penicillin-resistant, $\mathbf{P S}=$ penicillin-sensitive, $\mathbf{R}=$ reproductive ratio, $\mathbf{R P O}=$ retention pay-off.

Received May 19, 2005.

Accepted August 5, 2005.

Corresponding author: J. M. Swinkels; e-mail: swinkels@ innovet.nl.

\section{INTRODUCTION}

Staphylococcus aureus mastitis is a highly prevalent and costly disease. Control of $S$. aureus mastitis through preventive measures, dry cow treatment, and culling of infected animals can be economically profitable (Goodger and Ferguson, 1987; Zepeda et al., 1998). In addition to dry cow treatment, treatment of clinical mastitis is part of most standard mastitis control programs. By contrast, treatment of subclinical $S$. aureus mastitis during lactation is generally considered ineffective (Fox and Gay, 1993) and not economically justified when used as a stand-alone mastitis control strategy (Allore et al., 1998).

When treatment of $S$. aureus mastitis is postponed until the dry period, duration of infection increases. Indicators of chronic infection include prolonged periods or heightened levels of shedding of bacteria or somatic cells, palpable tissue changes, and infection of multiple quarters within a cow. All of the aforementioned factors are associated with a low probability of cure (Sol et al., 1997, 2000; Deluyker et al., 2005). In addition, long periods of infection and bacterial shedding create a prolonged window of opportunity for clinical mastitis to develop and for contagious transmission to occur (Lam et al., 1996; Zadoks et al., 2002a). Indirect effects of mastitis treatment (i.e., the prevention of clinical mastitis and transmission to other cows) are often overlooked in cost-benefit analyses but might tip the balance in favor of treatment (St. Rose et al., 2003; Swinkels et al., 2005). Some authors state that better cure rates are obtained by treating subclinical infections in lactation than by treating clinical cases of $S$. aureus mastitis (Bramley and Dodd, 1984). The chances of cure for cows that are subclinically infected with $S$. aureus can be improved by use of extended treatment (Deluyker et al., 2005) and by selection of treatmenteligible cows using current knowledge of risk factors for cure (Sol et al., 1997; Deluyker et al., 2005). Like inclusion of indirect effects, consideration of treatment and cow selection options will affect the outcome of costbenefit analysis for antimicrobial treatment.

To determine the profitability of lactational treatment with antimicrobials, potential benefits of treat- 
ment must be weighed against costs such as the price of antibiotics and loss of milk due to withholding times. The economic profitability of lactational treatment of subclinical mastitis has been demonstrated for Streptococcus agalactiae (Yamagata et al., 1987) and for nonagalactiae streptococci (Swinkels et al., 2005), but the value of lactational treatment of subclinical $S$. aureus mastitis has not been examined.

We explored the economic benefits of treating subclinical S. aureus mastitis during lactation under European conditions [milk quota in place, legal limit for bulk milk somatic cell count (BMSCC) $<400,000$ cells $/ \mathrm{mL}$ ] using partial budgeting. In this analysis, effects at the cow level, such as bacteriological cure and prevention of clinical mastitis, and effects at the herd level, specifically reduced transmission potential, were taken into account. In addition, knowledge of risk factors for cure was incorporated in the economic model, resulting in cow-specific outcomes for the profitability of lactational treatment of subclinical $S$. aureus mastitis.

\section{MATERIALS AND METHODS}

\section{Modeling Approach}

Partial budgeting was used to develop a deterministic simulation model that estimates the net cost or benefit of treatment of subclinical $S$. aureus mastitis during lactation. Input variables were based on the literature and on dairy prices and conditions in the Netherlands from 2003 to 2004 . The effect of 3-d treatment or 8-d treatment with antibiotics, both of which are registered for use in the Netherlands and other European countries, was compared with the effect of no treatment. In a partial budgeting model, economic effects are calculated as total revenues weighed against total costs. Treatment is profitable compared with no treatment when total revenues of treatment are higher than the total costs. Total revenues are calculated as extra revenue plus reduced costs. Total costs are calculated as reduced revenue plus extra costs. Costs and benefits of treatment were calculated at the cow level for one lactation.

First, a basic model was developed based on biological and economic parameters. Biological parameters included clinical outcome of infection with $S$. aureus and effects at herd level, specifically contagious transmission. The risk of transmission may vary considerably between herds, depending on herd management (Lam et al., 1996; Zadoks et al., 2002a) and strain factors (Smith et al., 1998; Zadoks et al., 2002a). Therefore, 4 scenarios were analyzed: 1) 3-d treatment in a herd with low risk of transmission, 2) 3-d treatment in a situation with high risk of transmission, 3) 8-d treatment with low risk of transmission, and 4) 8-d treat- ment with high risk of transmission. Economic parameters and calculations for each scenario are described. Numbers are rounded off in the text, but were not rounded off in calculations, which explains any discrepancies that may occur. Next, sensitivity analysis was performed for the 4 scenarios to identify input parameters with a strong impact on the model outcome. Finally, because cow and strain factors influence the probability of cure, the effect of these factors on economic benefits was explored.

\section{Biological Parameters in Basic Model}

Cure of persistent infections. In the Netherlands, the sampling interval for milk yield, SCC, and component testing is usually $4 \mathrm{wk}$. A cow is suspected of subclinical mastitis if at least 2 of 3 consecutive samples have cow-milk SCC above 250,000 cells $/ \mathrm{mL}$. It is recommended that a milk sample of such an animal be submitted for bacterial culture so that treatment and management decisions can be based on knowledge of the causative organism. If the causative organism is $S$. aureus, treatment can be considered. In this paper, we focus on treatment decisions for $S$. aureus infections that are detected using this sampling scheme, i.e., infections that have existed for at least $30 \mathrm{~d}$ (minimum of interval between 2 SCC measurements plus time needed for bacteriology). Such infections will be referred to as "persistent" throughout the paper.

Persistent subclinical mastitis may be left untreated, or a decision to treat can be made (Figure 1). Farmers can choose between short-term antibiotic treatment (3$\mathrm{d}$ treatment) and extended treatment (8-d treatment). Treatment can result in cure or in failure to cure. Untreated infections and infections that do not cure in response to treatment can cure spontaneously, continue to persist as subclinical infections, or develop into a clinical case of mastitis. Persistently infected animals may infect other animals. New infections may result in subclinical mastitis that cures spontaneously within $30 \mathrm{~d}$, in persistent subclinical mastitis, or in clinical mastitis (Figure 1). All clinical cases are assumed treated and the model does not cover remission of clinical mastitis to subclinical mastitis.

The probability of spontaneous cure of persistent infections is low. Deluyker et al. (2005) describe a bestcase scenario of $6 \%$ cure for untreated $S$. aureus infections. This best-case scenario applies to heifers in late lactation with low levels of bacterial shedding. For older animals, animals at less than 200 DIM, and animals with higher shedding levels, the probability of cure (PC) is even lower than 6\%. We assumed an average PC of $3 \%$ for untreated animals with persistent subclinical $S$. aureus infection (Figure 1). According to a meta- 


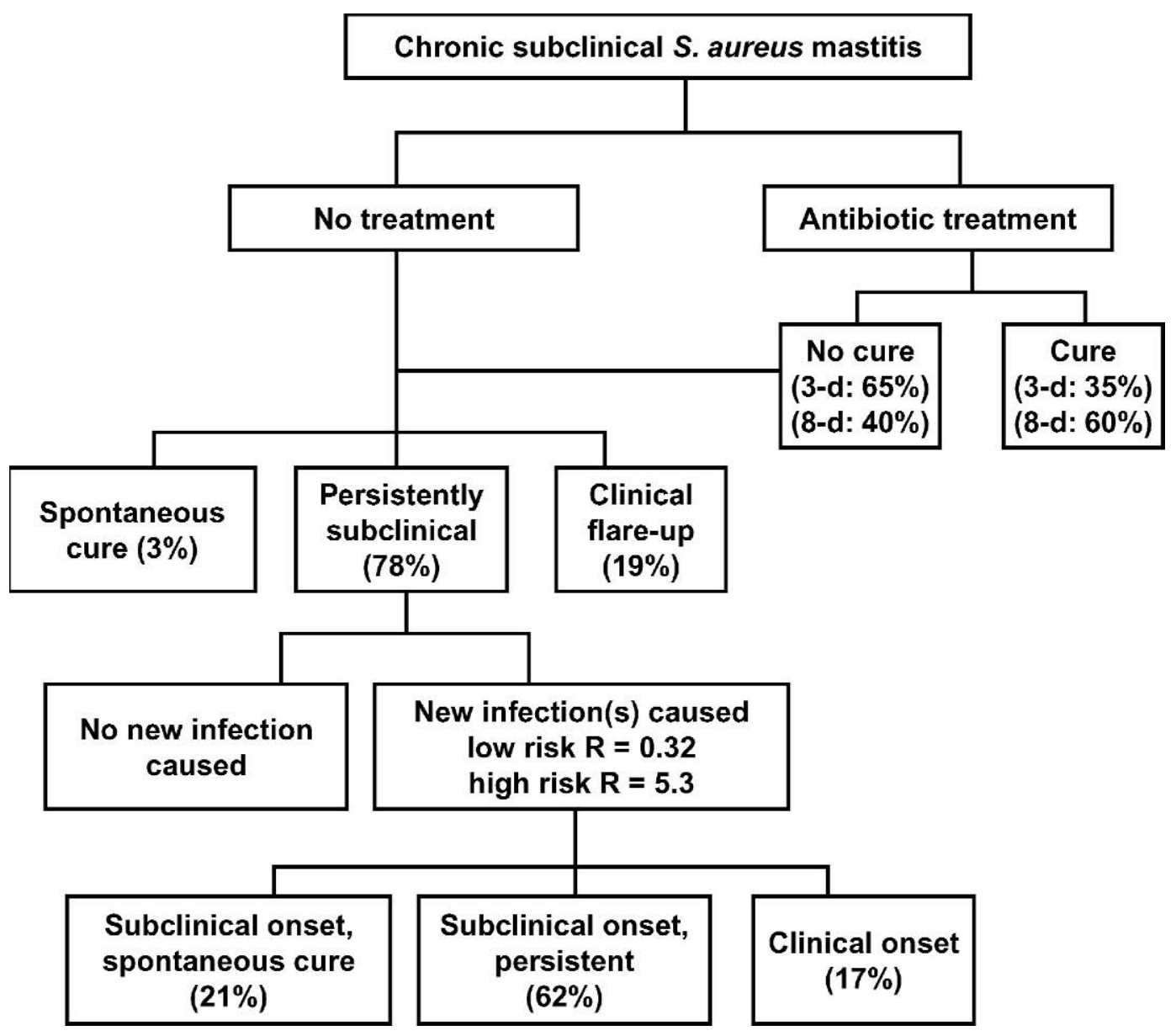

Figure 1. Deterministic model for effect of no treatment, 3-d treatment, or 8-d treatment on outcome of persistent subclinical Staphylococcus aureus mastitis. $\mathrm{R}$ = reproductive ratio (number of new infections caused by an existing infection).

analysis of treatment trials of subclinical $S$. aureus mastitis, $\mathrm{PC}$ for the average cow is $35 \%$ after short-term antibiotic treatment (Sol et al., 1997). This average PC is similar to the midpoint of the range of probabilities described by Deluyker et al. (2005). For short-term treatment with pirlimycin, $\mathrm{PC}$ ranges from 3 to $56 \%$. Probability of cure is $3 \%$ for a cow of parity $>3$ with high bacterial shedding levels in early lactation (worstcase scenario) and $56 \%$ for a heifer with low bacterial shedding levels in late lactation (best-case scenario). In the model, we used $35 \%$ as the chance of cure after 3$d$ treatment (Figure 1). Chances of cure increase with an increased duration of treatment (Ziv and Storper, 1985; Sol et al., 2000; Deluyker et al., 2005). After 8-d treatment, PC ranges from 10 to $86 \%$ (worst- and bestcase scenarios, respectively). For the model, we used the average $\mathrm{PC}$ for second- and third-lactation animals, which is approximately 60\% (Deluyker et al., 2005; Figure 1).
When infections persist, clinical flare-ups may occur. Lam (1996) reported 132 chronic $S$. aureus infections with subclinical onset. Twenty-three infections (17\%) showed clinical flare-ups. Original data from Zadoks et al. (2002a) included 76 persistent $S$. aureus infections of which 16 (21\%) showed clinical flare-ups. For the model, we used the average of the 2 percentages as the probability of clinical flare-ups, i.e., $19 \%$ of persistent infections were assumed to develop clinical signs (Figure 1).

Transmission of infections. Staphylococcus aureus is a contagious mastitis pathogen (Fox and Gay 1993; Lam et al., 1996). Subclinical S. aureus infections are a potential threat to uninfected cows and quarters in the herd. Contagiousness of a pathogen can be expressed in the transmission parameter, $\beta$, the average number of new infections caused by an infected individual per unit of time (Lam et al., 1996; Zadoks et al., 2002a). The actual number of new infections that is 
caused by an existing infection depends on the duration of the existing infection. The combined effect of contagiousness $(\beta)$ and duration of infection $(\tau)$ is represented by the reproductive ratio $R$, which is the total number of new infections caused by an existing infection during its infectious lifetime. The reproductive ratio, $\mathrm{R}$, can be presented as $\beta \times \tau$, or as $\beta / \alpha$, where $\alpha$ is the cure rate and equals the inverse of the duration of infection, i.e., $\alpha=1 / \tau$.

The duration of $S$. aureus infection has been described by Lam et al. $(1996,1997)$ for 7 farms with low average annual BMSCC ( $<150,000$ cells $/ \mathrm{mL})$. These data show that duration of infection differs with farm and management measures (postmilking teat disinfection vs. no disinfection). Average duration of infection was $115 \mathrm{~d}$ for disinfected quarters (Lam et al., 1997). For the model, the duration of infection for disinfected quarters was used, rather than the duration of infection for nondisinfected quarters, because postmilking teat disinfection is used on the majority of farms in the Netherlands (Barkema et al., 1998). Average duration of infection for herds with average annual BMSCC between 200,000 and 300,000 cells/mL also differed with herd and management strategy (Zadoks et al., 2002a). In a herd in which aggressive treatment or culling strategies were not implemented, average duration of persistent $S$. aureus infections was 118 d (original data for herd A from Zadoks et al., 2002a), which is similar to results from low BMSCC herds.

The transmission parameter, $\beta$, has been estimated for disinfected and nondisinfected quarters in a steadystate situation and during an outbreak in low BMSCC herds (Lam et al., 1996), and for medium BMSCC herds under various management conditions (Zadoks et al., 2002a). As best-case scenario (indicated by the subscript bc), we used $\beta_{\mathrm{bc}}=0.0028$ infections $/ \mathrm{d}$ for a steadystate situation with postmilking teat disinfection (Lam et al., 1996). From $\beta_{\mathrm{bc}}$ and $\tau$, the reproduction ratio for the best-case scenario can be calculated as $R_{b c}=\beta_{b c} \times$ $\tau=0.0028$ infections $/ \mathrm{d} \times 115 \mathrm{~d}=0.32$ infections (Figure 1). This value was slightly lower than values reported for medium BMSCC herds (0.40 to 0.75; Zadoks et al., 2002a). As worst-case scenario (indicated by the subscript wc), we used an outbreak situation in a herd where postmilking teat disinfection is not implemented. Estimates for $\beta_{\mathrm{wc}}$ and $\mathrm{R}_{\mathrm{wc}}$ are 0.046 infections/d (Lam et al., 1996) and 0.046 infections $/ \mathrm{d} \times 115 \mathrm{~d}=5.3$ infections, respectively (Figure 1). As described above, a subclinical infection is considered persistent and eligible for treatment when it has existed for $30 \mathrm{~d}$ or more. Usually, there is some delay between detection of a cow that is suspected of infection and a treatment decision. Furthermore, the onset of infection may have preceded the first high SCC measurement as infections can occur on any day and SCC is measured periodically. For model calculations, we assumed the interval between onset of infection and onset of treatment to be 6 wk. Hence, if treatment is successful, it reduces duration of infection from 115 to $42 \mathrm{~d}$, or by an average of $73 \mathrm{~d}$ compared with unsuccessful or no treatment. In a herd that implemented an aggressive strategy for detection and treatment of subclinically infected cows, observed duration for persistent subclinical infections was $51 \mathrm{~d}$ across cows, exemplifying that a lower average duration of infection can indeed be achieved under field conditions (original data for herd B from Zadoks et al., 2002a). In a low transmission scenario, a 73-d reduction in duration, equivalent to a prevented duration, $\tau_{\text {prev }}$, of $73 \mathrm{~d}$ is associated with prevention of $\beta_{\mathrm{bc}} \times \tau_{\text {prev }}=0.0028$ infections/ $\mathrm{d} \times 73 \mathrm{~d}=0.20$ new infections. In a high transmission scenario, the reduction in duration is associated with $\beta_{\mathrm{wc}} \times \tau_{\text {prev }}=0.046$ infections $/ \mathrm{d} \times 73 \mathrm{~d}=3.4$ new infections. The probability of transmission of infections depends on herd management, but also on strain factors that are beyond the manager's control (Smith et al., 1998; Zadoks et al., 2002a). Therefore, a low or high transmission scenario cannot always be equated to good or poor udder health management.

When transmission occurs, the onset of a new infection can be clinical or subclinical. The proportion of new infections with clinical onset was $11.5 \%$ in herds with medium BMSCC (Zadoks et al., 2002a) and $22.8 \%$ on farms with low BMSCC (Lam et al., 1996). For the model, we used the arithmetic average, $17 \%$, as probability that a new infection will have clinical onset (Figure 1). The remaining $83 \%$ of new infections have subclinical onset. Approximately 25\% of new infections with subclinical onset or $21 \%$ of all new infections cure spontaneously within $30 \mathrm{~d}$ (original data from Zadoks et al., 2002a). The remaining infections, i.e., 100\% $17 \%-21 \%=62 \%$ become persistently subclinical (Figure 1).

\section{Economic Parameters in Basic Model}

Extra revenue. An increase in milk production after treatment would be considered extra revenue. There are no studies that describe milk production after treatment of persistent subclinical $S$. aureus infections. McDermott et al. (1983) found no increase in milk production after antibiotic treatment of high SCC cows compared with animals that did not receive treatment. Similarly, there was no increase in milk production after treatment of persistent subclinical mastitis caused by non-agalactiae streptococci (St. Rose et al., 2003). Based on those studies, we assumed milk production increase after treatment to be zero (Table 1). 
Table 1. Overview of input variables used in the deterministic model and partial budget of economic benefit of lactational treatment of Staphylococcus aureus mastitis. Values for 8-d treatment are listed only when different from values for 3-d treatment.

\begin{tabular}{|c|c|c|c|}
\hline Input variable & Reference & \multicolumn{2}{|c|}{ Treatment } \\
\hline $\begin{array}{l}\text { Extra revenue } \\
\text { Increase in milk production after cure }(\mathrm{kg})\end{array}$ & St. Rose et al., 2003 & 0 & \\
\hline $\begin{array}{l}\text { Reduced costs } \\
\text { Prevention of clinical mastitis } \\
\text { Costs of clinical flare-up of preexisting subclinical mastitis }(€) \\
\text { Reduction in probability of clinical mastitis after treatment }(\%)\end{array}$ & $\begin{array}{l}\text { De Vos and Dijkhuizen, } 1998 \\
\text { Lam, 1996; Zadoks, } 2002\end{array}$ & $\begin{array}{r}187.0 \\
6.0\end{array}$ & 10.8 \\
\hline $\begin{array}{l}\text { Prevention of new infections } \\
\text { Cost of new clinical mastitis }(€) \\
\text { Cost of lost milk production }(€ / \mathrm{kg}) \\
\text { Cost of new short-duration subclinical mastitis }(€) \\
\text { Costs of new persistent subclinical mastitis }(€) \\
\text { Average costs of a new } S \text {. aureus infection }(€) \\
\text { Reduction in probability of cure of a new infection }(\%)\end{array}$ & $\begin{array}{l}\text { De Vos and Dijkhuizen, } 1998 \\
\text { De Vos and Dijkhuizen, } 1998 \\
\text { Current study } \\
\text { Current study }\end{array}$ & $\begin{array}{c}233 \\
0.07 \\
1.98 \\
111.30 \\
109 \\
34.0\end{array}$ & 58.2 \\
\hline $\begin{array}{l}\text { Extra costs } \\
\text { Antibiotics }(€ / \mathrm{d}) \\
\text { Bacteriological culturing ( } € / \text { test) } \\
\text { Number of quarters tested }\end{array}$ & $\begin{array}{l}\text { Current study } \\
\text { Current study } \\
\text { Current study }\end{array}$ & $\begin{array}{l}9 \\
4.19 \\
2\end{array}$ & \\
\hline
\end{tabular}

Reduced costs. Successful treatment of persistent subclinical mastitis may prevent and thus reduce other costs. Costs can be reduced due to: 1) prevention of clinical mastitis in the infected cow; 2) prevention of culling of the infected cow; 3) prevention of new infections in other cows; 4) prevention of penalties for high SCC (Allore et al., 1998); and 5) prevention of losses due to poor fertility (Schrick et al., 2001). The last 2 factors were not considered in the model, although penalties and bonuses can be important factors in the economics of mastitis (Allore et al., 1998).

Reduced cost due to prevention of clinical mastitis. When a new $S$. aureus infection starts out as a clinical case of mastitis, its cost is estimated at $€ 233$ (De Vos and Dijkhuizen, 1998). This estimate includes the cost of lost milk production (estimated at $€ 93$ ), culling, antibiotic treatment, and discarded milk. Clinical $S$. aureus mastitis can also be the result of the flareup of a preexisting subclinical infection. In that case, some milk loss has already occurred during the subclinical phase of infection, and additional milk loss due to the clinical episode will be lower than for a clinical episode that signals the onset of a new infection. We assumed milk production loss associated with clinical flare-ups to be $50 \%$ less than for new infections. The resulting estimated cost for clinical flare-ups is $€ 233-$ $(0.5 \times € 93)=€ 187$ (Table 1$)$. As described above, the probability of a clinical flare-up is estimated at $19 \%$ for persistent infections (Figure 1). After 3-d treatment, $65 \%$ of persistent infections remain uncured and $19 \%$ of those will show clinical flare-ups, so that $19 \%$ of $65 \%=12.4 \%$ of quarters that receive 3 -d treatment are expected to show clinical flare-ups. For 8-d treatment, $60 \%$ cure and $40 \%$ noncure is expected and $19 \%$ of $40 \%=$ $7.6 \%$ of quarters that receive 8 -d treatment will develop clinical signs. Untreated quarters are expected to show clinical flare-ups in $19 \%$ of uncured infections, i.e., in $19 \%$ of $97 \%=18.4 \%$ of untreated infections. Comparison of untreated and treated quarters shows that the reduction in probability of clinical flare-ups is $18.4 \%-$ $12.4 \%=6.0 \%$ for 3 -d treatment, and $18.4 \%-7.6 \%=$ $10.8 \%$ for 8 -d treatment (Table 1 ). The associated reduction in cost is $6.0 \%$ or $10.8 \%$ of $€ 187$, i.e., $€ 11.36$ and $€ 20.25$, respectively (Table 2 ).

Reduced cost due to prevention of culling. Successful treatment decreases the probability of culling for infected animals. Of all culled animals, 5 to $17 \%$ are culled for mastitis-related reasons (Beaudeau et al., 1993; Esslemont and Kossaibati, 1997; Seegers et al., 1998; Whitaker et al., 2000). The high end of that range is close to the average culling percentage of $17.6 \%$ reported for a number of research herds in the Netherlands (Smolders, 1994). For our model, we assumed that $15 \%$ of all culls were due to mastitis. A large propor- 
Table 2. Net profit of 3-d or 8-d lactational treatment of persistent subclinical Staphylococcus aureus mastitis compared with no treatment when risk of contagious transmission is low $(R=0.32)$ or high $(R=5.3)$.

\begin{tabular}{|c|c|c|c|c|}
\hline \multirow[b]{3}{*}{ Input } & \multicolumn{4}{|c|}{ Net $_{\text {profit }}{ }^{1}(€)$} \\
\hline & \multicolumn{2}{|c|}{$\mathrm{R}=0.32$} & \multicolumn{2}{|c|}{$\mathrm{R}=5.3$} \\
\hline & $3 \mathrm{~d}$ & $8 \mathrm{~d}$ & $3 \mathrm{~d}$ & $8 \mathrm{~d}$ \\
\hline \multicolumn{5}{|l|}{ Extra revenue } \\
\hline Milk production increase after cure & 0 & 0 & & \\
\hline Subtotal & 0 & 0 & & \\
\hline \multicolumn{5}{|l|}{ Reduced costs } \\
\hline Revenues of reduced clinical mastitis & 11.36 & 20.25 & & \\
\hline Reduced costs due to culling & 16.58 & 28.42 & & \\
\hline Prevented costs new infections & 7.57 & 12.97 & 124.30 & 213.09 \\
\hline Subtotal & 35.51 & 61.64 & 152.25 & 261.76 \\
\hline \multicolumn{5}{|l|}{ Reduced revenue } \\
\hline Withheld milk & 21.25 & 38.96 & & \\
\hline Subtotal & 21.25 & 38.96 & & \\
\hline \multicolumn{5}{|l|}{ Extra costs } \\
\hline Antibiotics & 27.00 & 72.00 & & \\
\hline Bacteriological culture & 8.38 & 8.38 & & \\
\hline Labor & 0 & 0 & & \\
\hline Costs of penalty for antibiotic residue & 0 & 0 & & \\
\hline Subtotal & 35.38 & 80.38 & & \\
\hline Net result & -21.12 & -57.70 & 95.62 & 142.42 \\
\hline
\end{tabular}

${ }^{1}$ Net profit is calculated as (extra revenue + reduced costs) minus (reduced revenue + extra costs). $\mathrm{R}=$ reproductive ratio; values for $R=5.3$ are listed only when different from values for $R=0.32$.

tion of mastitis related culls, estimated at 50 to $65 \%$, is due to subclinical mastitis (personal experience of and personal communications to J. M. Swinkels). On Dutch farms, culling averages $34 \%$ of the herd annually (NRS, 2003-2004). Culling due to subclinical mastitis can now be calculated as the proportion subclinical out of proportion culled because of mastitis out of total proportion culled, i.e., $50 \%$ of $15 \%$ of $34 \%=3 \%$ of the total number of cows in a herd. In a herd with average BMSCC of 200,000 to 300,000 cells $/ \mathrm{mL}$, approximately $25 \%$ of animals are subclinically infected (Eberhart et al., 1982). Hence, the probability of culling for an individual subclinically infected cow is $3 \%: 25 \%=12 \%$ (Table 1). The retention pay-off (RPO) is an economic index that represents the future profitability of an animal. The RPO depends on parity, stage of lactation, pregnancy, milk production, and other factors. Calculations for RPO have been described by Houben et al. (1994). Using Houben's method, we calculated the RPO of a second-parity cow at $7 \mathrm{mo}$ of lactation and $2 \mathrm{mo}$ of gestation to be $€ 506$ (Table 1). Prices were adapted to the 2004 situation in the Netherlands.

Reduced costs due to culling can be calculated as the probability of culling without treatment minus the probability of culling after treatment multiplied by the costs of culling. Culling due to subclinical mastitis is largely limited to persistently infected animals. Without treatment, the probability of persistent subclinical infection is $78 \%$ (Figure 1). After 3-d treatment, the probability of persistent infection is $65 \% \times 78 \%=51 \%$. Compared with untreated cows, this is a reduction in probability of persistent infection of $78 \%-51 \%=27 \%$ (Table 1). After 8-d treatment, the probability of persistent infection is $40 \%$ of $78 \%=31 \%$ and the reduction in probability of persistent infection is $78 \%-31 \%=$ $47 \%$ (Table 1). Twelve percent of persistently infected animals are assumed culled, as described earlier. The average cost of culling due to subclinical mastitis is therefore $12 \%$ of the estimated cull cost of $€ 506$ per animal, i.e., €60.7. The reduction of costs due to culling is thus $27 \%$ of $€ 60.7=€ 16.58$ and $47 \%$ of $€ 60.7=€ 28.42$ for 3- and 8-d treatment, respectively (Table 2).

Reduced cost due to prevention of new infections. Although prevented cost of clinical mastitis and prevented cost of culling as described above pertain to the animal that receives treatment (i.e., the animal with the primary infection), there is also a reduced cost due to prevention of new or secondary infections in other animals. New infections can manifest as clinical mastitis, subclinical mastitis with short duration, or persistent subclinical mastitis (Figure 1), and each manifestation is associated with a cost. The reduced cost due to prevention of new infections is based on the average cost of a new infection, and the number of new infections that is prevented by a specific treatment given the level of risk of contagious transmission. As quoted previously, the cost of a new infection that manifests as clinical mastitis is estimated at $€ 233$ (De Vos 
and Dijkhuizen, 1998) (Table 1). The cost of a new case of subclinical mastitis is primarily the result of reduced production and, if the subclinical mastitis becomes persistent, of potential clinical flare-ups and culling. To avoid a snowball effect and keep the model manageable, we did not include the cost of tertiary infections that are potentially prevented by prevention of secondary infections.

Milk production losses resulting from subclinical mastitis are correlated with SCC. Production loss for a cow with SCC of 50,000 cells $/ \mathrm{mL}$ or below is set at zero (Hortet and Seegers, 1998). Every doubling of SCC is associated with a production loss of $0.4 \mathrm{~kg} / \mathrm{d}$ for heifers and $0.6 \mathrm{~kg} / \mathrm{d}$ for cows (Hortet and Seegers, 1998). The average SCC of quarters with persistent subclinical $S$. aureus infection is $\mathrm{e}^{7.13}=1.2 \times 10^{6}$ cells $/ \mathrm{mL}$ (Table 1 from Deluyker et al., 2005). In the Netherlands, the average number of infected quarters per $S$. aureus-infected cow is 1.675 (Poelarends et al., 2001). When the remaining 2.375 quarters of a cow are assumed uninfected, the average SCC of a cow with persistent subclinical $S$. aureus mastitis is estimated at $[1.675 \times 1.2$ $\left.\times 10^{6}+2.375 \times 50,000\right] / 4=5.5 \times 10^{5}$ cells $/ \mathrm{mL}$. This is a 3.5-fold doubling of the healthy baseline SCC of 50,000 cells $/ \mathrm{mL}$, and is thus associated with a production loss of $3.5 \times 0.4=1.4 \mathrm{~kg} / \mathrm{d}$ for heifers and $3.5 \times 0.6=2.1 \mathrm{~kg}$ for cows. If there is no milk quota system (as in the United States), the cost of lost milk production is equal to the amount of lost milk multiplied by the milk price. In the European Union, where a quota system is in place, loss of milk is usually compensated for by the extra milk production of animals that are kept in the herd beyond their intended cull date. Therefore, the cost of lost milk production is lower when a milk quota is in place than in a nonquota situation; this cost is estimated at $€ 0.07 / \mathrm{kg}$ of milk (De Vos and Dijkhuizen, 1998; Table 1).

A new subclinical infection can cure spontaneously within $30 \mathrm{~d}$, i.e., before the next routine milk sampling. We assumed the average duration of a spontaneously cured infection to be $15 \mathrm{~d}$. For a heifer, the production loss associated with short-term subclinical infection was calculated to be $1.4 \mathrm{~kg} / \mathrm{d} \times 15 \mathrm{~d}=21 \mathrm{~kg}$. For a multiparous cow, it was calculated as $2.1 \mathrm{~kg} / \mathrm{d} \times 15 \mathrm{~d}=$ $32 \mathrm{~kg}$. Assuming that approximately one-third of a herd consists of heifers, the average costs of new infections that cure spontaneously within $30 \mathrm{~d}$ are estimated to be $(1 / 3 \times 21+2 / 3 \times 32) \mathrm{kg} \times € 0.07 / \mathrm{kg}=€ 1.98$ (Table 1$)$.

For new subclinical infections that persist, average duration was estimated at $115 \mathrm{~d}$, and the average production loss was estimated at $1.4 \mathrm{~kg} / \mathrm{d} \times 115 \mathrm{~d}=161 \mathrm{~kg}$ for heifers, and $2.1 \mathrm{~kg} / \mathrm{d} \times 115 \mathrm{~d}=242 \mathrm{~kg}$ for multiparous cows. The average estimated milk production loss would be $1 / 3 \times 161 \mathrm{~kg}+2 / 3 \times 242 \mathrm{~kg}=215 \mathrm{~kg}$. This amounts to a loss of $215 \mathrm{~kg} \times € 0.07 / \mathrm{kg}=€ 15.05$. Persistent subclinical mastitis also has the cost associated with clinical flare-ups and culling. The cost of flare-ups is $€ 187$ and this cost is incurred in $19 \%$ of persistent infections, amounting to an average loss of $19 \% \times € 187=$ $€ 35.53$ per persistent infection. The cost associated with culling is $€ 60.72$, as calculated for treated cows. Thus, the total cost of new subclinical infections that become persistent is $€ 15.05+€ 35.53+€ 60.72=€ 111.30$ (Table 1).

New infections that result from transmission can have clinical onset ( $17 \%$ of infections, cost $€ 233$ per infection), subclinical onset and short duration (21\% of infections, cost $€ 1.98$ per infection), or subclinical onset and long duration ( $62 \%$ of infections, cost $€ 111.30$ per infection), resulting in an average cost of new infections of $0.17 \times € 233+0.21 \times € 1.98+0.62 \times € 111.30=€ 109$ (Table 1). Probability of cure after treatment is 35 and $60 \%$ for 3 - and 8 -d treatment, respectively. The remaining 65 and $40 \%$ of animals have a $3 \%$ chance of curing spontaneously, as do untreated animals. Total PC is thus $3 \%$ for untreated animals, $35 \%$ plus $3 \%$ of $65 \%=37 \%$ for animals after 3 -d treatment, and $60 \%$ plus $3 \%$ of $40 \%=61.2 \%$ after 8 -d treatment. Hence, $3-$ $\mathrm{d}$ and 8-d treatments are associated with a $34 \%$ and a $58.2 \%$ higher chance of cure, respectively, than no treatment (Table 1). As described under "transmission of infections," the number of prevented infections that can be attributed to an infection that is cured is estimated at 0.2 in a low-transmission scenario, and at 3.4 in a high-transmission scenario. The prevented costs due to prevention of transmission of infection can now be calculated as $34 \%$ of $0.2 \times € 109=€ 7.57$ for 3 -d treatment in a low-transmission herd, $34 \%$ of $3.4 \times € 109=$ $€ 124.30$ for 3 -d treatment in a high-transmission herd, $58 \%$ of $0.2 \times € 109=€ 12.97$ for 8 -d treatment in a lowtransmission herd, and $58 \%$ of $3.4 \times € 109=€ 213.08$ for 8-d treatment in a high-transmission herd (Table 2).

Reduced revenue. Treatment with antibiotics results in residues in the milk; this milk is not suitable for human consumption and has to be discarded. Withholding or discarding milk leads to reduced revenue. The average costs of discarded milk were estimated at $€ 0.14 / \mathrm{kg}$. (De Vos and Dijkhuizen, 1998; Table 1). When a quota system is in place, the cost of discarded milk is higher than the cost of milk that is lost due to high SCC. The difference in economic value arises because the cost of concentrates is included in the value for discarded milk but not in the value of nonproduced milk. We assumed the milk-withholding period after completion of treatment to be $3 \mathrm{~d}$. This is based on the average withholding period of $4 \mathrm{~d}$ of the 2 currently registered and marketed antibiotics on the Dutch market and the assumption that the day of last treatment 
is counted as a day for withholding milk. Thus, total milk withhold times are 6 and $11 \mathrm{~d}$ for 3 -d and 8-d treatment, respectively. Average milk production was assumed $25.3 \mathrm{~kg} / \mathrm{d}$ (NRS, 2003-2004; Table 1). Total costs of withheld milk can be calculated as $6 \mathrm{~d} \times 25.3$ $\mathrm{kg} / \mathrm{d} \times € 0.14 / \mathrm{kg}=€ 21.25$ and $11 \mathrm{~d} \times 25.3 \mathrm{~kg} / \mathrm{d} \times € 0.14 /$ $\mathrm{kg}=€ 38.96$ for 3 - and 8-d treatment, respectively (Table 2).

Extra costs. The extra costs of treatment vs. no treatment are costs of antibiotics, diagnostic testing, extra labor, and potential penalties due to antibiotic residues in milk. The cost of antibiotics depends on the choice of drug, route of administration, dosage, and length of treatment. Registered products for the treatment of subclinical mastitis in the Netherlands are commercially available to producers at an average cost of $€ 9 /$ $\mathrm{d}$ (Table 1). This results in extra costs of $€ 27$ and $€ 72$ for 3- and 8-d treatments, respectively (Table 2). Risk factors for cure of persistent subclinical mastitis include the location of the infected quarter(s) and penicillin sensitivity (PS) of the S. aureus strain that causes infection (Sol et al., 1997, 2000; Deluyker et al., 2005). When treatment decisions are to be made using knowledge of these risk factors, quarter location and PS need to be determined. Quarter location can be determined using the California mastitis test. The cost of the California mastitis test was considered negligible. To determine PS, bacteriological culture and PS testing are needed. The cost of such testing is $€ 4.19$ per quarter (Animal Health Service, Deventer, the Netherlands; Table 1). Taking into consideration that cows infected with $S$. aureus have more than one infected quarter on average (Poelarends et al., 2001), we used an average cost of testing of $2 \times € 4.19=€ 8.38$ per cow (Table 2 ). In some cases, testing will not result in detection of $S$. aureus, and $S$. aureus treatment will not be given. This decreases the extra cost of treated cows relative to nontreated cows. The probability of negative cultures is highly farm-dependent. Culture may also result in detection of Streptococcus dysgalactiae or Streptococcus uberis, which could be a reason for treatment (Swinkels et al., 2005). Because it is difficult to estimate the cost of culture for $S$. aureus negative cows and because a decision not to treat can be made without culture, whereas a decision to treat is assumed culture-based, we did not include costs of negative cultures in the model. Extra costs for labor have to be taken into account if time saved by not treating the animal can be used for other paid labor. This is not likely on the majority of farms in the Netherlands because most dairy farms are family farms where farm income is based on the amount of milk that is produced, not on hours of labor. Therefore, we assumed the extra costs of labor to be zero (Table 2). Extra costs resulting from penalties for antibiotic residue in the bulk tank are assumed zero because these costs can and should be prevented through good management (Table 2).

\section{Sensitivity Analysis for Basic Model}

Sensitivity analysis is used to calculate what happens to model output when one input variable at a time is changed from the average situation. Sensitivity analysis was performed for 4 scenarios, i.e., 3-d treatment or 8-d treatment combined with low $(\mathrm{R}=0.32)$ or high $(\mathrm{R}=5.3)$ risk of $S$. aureus transmission. For each scenario, the impact of a change in model input on model output was calculated. The impact of all input variables listed in Figure 1 or Table 1 on model output was determined. For the 6 most influential input variables, the impact of multiple levels of the variable on model output was tabulated (Table 3).

\section{Impact of Risk Factors for Cure}

In the basic model, an average probability of bacteriological cure of 35 and $60 \%$ was used for 3-d and 8-d treatments, respectively. However, bacteriological cure of $S$. aureus infections is not a random event. Host, pathogen, and management factors that influence PC include parity, stage of lactation, quarter location, quarter SCC, PS, and duration of treatment (Sol et al., 1997, 2000; Deluyker et al., 2005). The impact of various variables on cure has been quantified, which enables us to predict PC for each cow-pathogen-treatment combination. The prediction equation was adapted from Sol and colleagues (1997) and is described by: $\mathrm{PC}=100 \times 1 /\{1$ $+\operatorname{EXP}[-1-$ (intercept + parity + stage of lactation + quarter location + quarter SCC + PS + treatment regimen)]\}. This prediction equation differs from that originally given for lactational treatment of subclinical mastitis in that the effects of PS and treatment regimen were added to the equation. Probability of cure after treatment of subclinical $S$. aureus mastitis was not significantly different between PS and penicillin-resistant (PR) strains in the original analysis, but a considerable numerical difference was observed, i.e., 35\% cure for PS strains and 25\% cure for PR strains (Sol et al., 1997). In a similar study of risk factors for cure after treatment of clinical S. aureus mastitis, PS strains were again associated with a higher probability of cure than were PR strains (58\% for PS vs. $41 \%$ for PR), and this difference was significant (Sol et al., 2000). Ziv and Storper (1985) report 56 and $32 \%$ cure after treatment of clinical $S$. aureus mastitis caused by PS and PR strains, respectively. Because PS was repeatedly shown to influence the chance of cure and because PS is determined for $S$. aureus isolates by the Dutch Animal Health Service as 
Table 3. Sensitivity analysis: Effect of the 6 most influential input variables for 3-d or 8-d treatment of subclinical Staphylococcus aureus mastitis on net profit in herds with low $(\mathrm{R}=0.32)$ or high risk of transmission $(\mathrm{R}=5.3)$.

\begin{tabular}{|c|c|c|c|c|}
\hline \multirow[b]{3}{*}{ Input } & \multicolumn{4}{|c|}{ Net profit $(€)$} \\
\hline & \multicolumn{2}{|c|}{$R=0.32$} & \multicolumn{2}{|c|}{$\mathrm{R}=5.3$} \\
\hline & $3 \mathrm{~d}$ & $8 \mathrm{~d}$ & $3 \mathrm{~d}$ & $8 \mathrm{~d}$ \\
\hline \multicolumn{5}{|l|}{ Bacteriological cure (\%) } \\
\hline 10 & -47.24 & -109.95 & -13.89 & -76.60 \\
\hline 20 & -36.79 & -99.50 & 29.91 & -32.80 \\
\hline 35 (current study; 3 -d treatment) & -21.12 & -83.83 & 95.62 & 32.91 \\
\hline 50 & -5.44 & -68.15 & 161.32 & 98.61 \\
\hline 60 (current study; 8-d treatment) & 5.01 & -57.70 & 205.13 & 142.42 \\
\hline 80 & 25.91 & -36.80 & 292.73 & 230.02 \\
\hline 90 & 36.36 & 26.35 & 336.54 & 273.83 \\
\hline 100 & 46.81 & -15.90 & 380.34 & 317.63 \\
\hline \multicolumn{5}{|c|}{ Proportion (\%) culled for subclinical mastitis } \\
\hline & -40.31 & -90.60 & 36.12 & 40.42 \\
\hline 12 (current study) & -21.12 & -57.70 & 95.62 & 142.42 \\
\hline 20 & -8.33 & -35.77 & 135.28 & 210.41 \\
\hline \multicolumn{5}{|l|}{ Retention pay off $(€)$} \\
\hline & -40.31 & -90.60 & 36.12 & 40.42 \\
\hline 506 (current study) & -21.12 & -57.70 & 95.62 & 142.42 \\
\hline 1000 & -2.38 & -25.59 & 153.70 & 241.99 \\
\hline \multicolumn{5}{|l|}{ Antibiotic costs $(€)$} \\
\hline 15 & -9.12 & -0.70 & 107.62 & 199.42 \\
\hline 27 (current study; 3 -d treatment) & -21.12 & -12.70 & 95.62 & 187.42 \\
\hline 50 & -44.12 & -35.70 & 72.62 & 164.42 \\
\hline 72 (current study; 8-d treatment) & -66.12 & -57.70 & 50.62 & 142.42 \\
\hline \multicolumn{5}{|l|}{ Price of discarded milk $(€)$} \\
\hline 0.00 & 0.13 & -18.74 & 116.87 & 181.38 \\
\hline 0.07 & -10.50 & -38.22 & 106.24 & 161.90 \\
\hline 0.14 (current study) & -21.12 & -57.70 & 95.62 & 142.42 \\
\hline 0.21 & -31.75 & -77.18 & 84.99 & 122.94 \\
\hline 0.30 & -45.41 & -102.23 & 71.33 & 97.89 \\
\hline \multicolumn{5}{|l|}{ Costs of bacterial culture $(€)$} \\
\hline 0.00 & -12.74 & -49.32 & 104.00 & 150.80 \\
\hline 4.19 (1 sample) & -16.93 & -53.51 & 99.81 & 146.61 \\
\hline 8.38 (2 samples; current study) & -21.12 & -57.70 & 95.62 & 142.42 \\
\hline 16.76 (4 samples) & -29.50 & -66.08 & 87.24 & 134.04 \\
\hline
\end{tabular}

part of routine bacteriological testing, we decided to include this variable in the model. Similarly, although the original study of lactational treatment of subclinical S. aureus mastitis (Sol et al., 1997) did not consider treatment duration, a study of treatment of clinical mastitis by the same authors (Sol et al., 2000), a study in 8 dairy herds (Ziv and Storper, 1985), and a large multicenter study comparing short and extended lactational therapy of subclinical mastitis (Deluyker et al., 2005) showed a significant effect of treatment duration on cure. In the prediction equation, intercept (0.40) and regression coefficients from Sol et al. (1997) were used for parity $(-1.05$ for parity $>2)$, DIM $(-1.90$ for DIM $\leq$ $100,-0.95$ for $100<\mathrm{DIM} \leq 200)$, quarter position $(-1.53$ for hind quarter), and quarter SCC $(-1.25$ for $\operatorname{lnSCC}$ $>6.9$ ). The regression coefficient for PS vs. $P R$ was calculated from the average cure rate for PS and PR infections ( 35 and $25 \%$, respectively) and was -0.49 for infections with PR $S$. aureus. The regression coefficient for extended treatment was calculated using best-case scenarios for short and extended treatment. According to Sol et al. (1997), the best-case PC is $61 \%$, which is very similar to the best-case PC of 56\% reported by Deluyker et al. (2005) for short-term treatment. In both studies, the best-case scenario applies to a first-lactation animal at more than 200 DIM. If such an animal is treated for $8 \mathrm{~d}, \mathrm{PC}$ is $86 \%$ (Deluyker et al., 2005). Using the prediction equation and $61 \%$ vs. $86 \%$ as PC, the regression coefficient for extended therapy was calculated at +1.42 . Our best-case scenario then becomes a heifer at $>200$ DIM that is infected in a front quarter with a PS $S$. aureus strain resulting in $\operatorname{lnSCC}<6.9$ and that receives extended therapy. Its $\mathrm{PC}=100 \times 1 /\{1+\mathrm{EXP}[-1$ $\times(0.40+0+0+0+0+0+1.42)]\}=86 \%$. The worstcase scenario is an older animal at $<100$ DIM infected in a hind quarter with a PR strain resulting in $\operatorname{lnSCC}$ $>6.9$. Short-duration treatment of this animal would 
result in $\mathrm{PC}=100 \times 1 /\{1+\operatorname{EXP}[-1 \times(0.40-1.05-1.90$ $-1.53-1.25-0.49+0)]\}=0.3 \%$.

\section{RESULTS}

Net profits for the basic model are presented in Table 2 for 3 -d and 8-d treatments under low- and high-transmission conditions. In herds where contagious transmission of $S$. aureus is very likely $(\mathrm{R}=5.3), 3$-d and 8$\mathrm{d}$ treatment result in high positive net profits of $€ 95.62$ and $€ 142.42$, respectively. When the probability of $S$. aureus transmission is low $(\mathrm{R}=0.32)$, the average economic benefit of both treatments is negative with a calculated net profit of $-€ 21.12$ and $-€ 57.70$ for $3-d$ and 8-d treatment, respectively.

Bacteriological cure, culling due to subclinical mastitis, retention pay-off, antibiotic costs, price of discarded milk, and bacteriological culturing were the 6 most influential input variables identified during sensitivity analysis of the basic model. Table 3 shows the net benefit at various levels of each variable for the 4 scenarios covered in this paper. For example, in herds with low transmission $(\mathrm{R}=0.32)$, 3-d treatment was profitable if the chance of cure was higher than approximately $55 \%$. In herds with high transmission $(\mathrm{R}=5.3)$, 3-d and 8-d treatments were profitable at predicted cure probabilities of 13 and $28 \%$, respectively.

A detailed analysis of the effect of host- and pathogenspecific risk factors on net benefit is presented in Tables 4 and 5. To limit the size of the tables, they do not include all possible combinations of parity, SCC, DIM, and quarter. Combinations with a predicted net profit less than $-€ 51$ for 3 -d treatment (Table 4) or less than -106 for 8-d treatment (Table 5) are not shown. Probability of cure ranges from less than 1 to $86 \%$ and associated net benefits range from less than $-€ 106$ to $+€ 257$ (Table 5). In herds with low transmission of S. aureus, 3 -d treatment is only expected to be profitable for young animals in late lactation that are infected in front quarters. In herds with high transmission of $S$. aureus, 3$\mathrm{d}$ treatment can be profitable for both young and old animals. However, older animals would have to be infected in front quarters, have low cow-milk SCC, and be treated in late lactation for treatment to be economically justified (Table 4). Extended treatment is not economically profitable in herds with low transmission of $S$. aureus. By contrast, if the risk of transmission is high, 8-d treatment is economically justified for the majority of risk factor combinations (Table 5). The bestand worst-case transmission scenarios shown in Tables 4 and 5 are extremes and occur in a minority of herds only. In many herds, $S$. aureus prevalence is more or less constant, implying that every infection is on average replaced by one new infection, i.e., $R=1$. Net bene- fits for herds in which $R=1$ were slightly higher than to those for low-transmission herds. At $R=1$, a positive net result was obtained for 3-d treatment of young animals with low cow-milk SCC and infected front quarters in late lactation, irrespective of antibiotic sensitivity of the organism, and for 8-d treatment of such animals with infection by a PS strain (results not shown). Note that Tables 4 and 5 include cow-specific risk factors for cure, but not other cow-specific factors that may affect net benefit, such as RPO or milk yield.

\section{DISCUSSION}

It is widely believed that treatment of subclinical $S$. aureus mastitis during lactation is ineffective and uneconomic. Nevertheless, antibiotics that are specifically registered for lactational treatment of subclinical mastitis are being marketed and promoted in Europe, where the maximum acceptable level of BMSCC is 400,000 cells $/ \mathrm{mL}$. Treatment of persistent subclinical streptococcal mastitis during lactation can be profitable when indirect effects of cure (i.e., prevention of clinical flare-ups and prevention of transmission to other animals) are taken into account (Swinkels et al., 2005). In the cost-benefit analysis presented here, we show that the profitability of lactational treatment of $S$. aureus mastitis depends strongly on host, pathogen, and herd factors and that treatment is economically justified in a variety of situations.

Treatment is economically profitable for many cows when the likelihood of contagious transmission of $S$. aureus is high. Although some strains of $S$. aureus can be highly contagious even under good management conditions (Smith et al., 1998), contagious transmission is usually the result of suboptimal udder health management, e.g., failure to use postmilking teat disinfection (Lam et al., 1996; Barkema et al., 1998). When udder health management is suboptimal, management changes need to be implemented to reduce the incidence of infection. In the Netherlands, close to $40 \%$ of farmers do not implement postmilking teat disinfection (Barkema et al., 1998); use of teat dips with proven efficacy should be recommended on such farms. Successful treatment of persistent $S$. aureus mastitis with antibiotics will also result in reduced incidence of new infections because it decreases the exposure of uninfected individuals to the pathogen. The herd level effect of treatment is an important element of its economic justification, as shown by the difference between low- and high-transmission scenarios in Tables $2,3,4$, and 5 . It must be emphasized that the term "persistent" $S$. aureus mastitis is used in our paper to describe any infection that has been present for $30 \mathrm{~d}$ or more. That does not imply that all cows that have been infected 
Table 4. Sensitivity analysis of host, pathogen, and treatment factors on net benefit of 3-d treatment of subclinical Staphylococcus aureus mastitis during lactation on farms with low $(\mathrm{R}=0.32)$ or high risk of transmission $(\mathrm{R}=5.3)$.

\begin{tabular}{|c|c|c|c|c|c|c|c|}
\hline \multirow[b]{2}{*}{ Pathogen } & \multirow[b]{2}{*}{$\mathrm{PC}^{1}(\%)$} & \multicolumn{4}{|c|}{ Cow factors } & \multirow[b]{2}{*}{$\mathrm{R}^{5}=0.32$} & \multirow[b]{2}{*}{$\mathrm{R}=5.3$} \\
\hline & & Parity $^{2}$ & $\mathrm{SCC}^{3}$ & $\mathrm{DIM}^{4}$ & Quarter & & \\
\hline \multirow[t]{15}{*}{ Penicillin-sensitive } & 18.2 & Young & Low & Early & Front & -39 & 22 \\
\hline & 36.6 & Young & Low & Mid & Front & -19 & 103 \\
\hline & 59.9 & Young & Low & Late & Front & 5 & 205 \\
\hline & 6.0 & Young & High & Early & Front & -51 & -31 \\
\hline & 14.2 & Young & High & Mid & Front & -43 & 5 \\
\hline & 29.9 & Young & High & Late & Front & -26 & 73 \\
\hline & 11.1 & Young & Low & Mid & Hind & -46 & -10 \\
\hline & 24.4 & Young & Low & Late & Hind & -32 & 49 \\
\hline & 8.5 & Young & High & Late & Hind & -49 & -20 \\
\hline & 7.2 & Old & Low & Early & Front & -50 & -26 \\
\hline & 16.8 & Old & Low & Mid & Front & -40 & 16 \\
\hline & 34.3 & Old & Low & Late & Front & -22 & 93 \\
\hline & 5.5 & Old & High & Mid & Front & -52 & -34 \\
\hline & 13.0 & Old & High & Late & Front & -44 & -1 \\
\hline & 10.2 & Old & Low & Late & Hind & -47 & -13 \\
\hline \multirow[t]{17}{*}{ Penicillin-resistant } & 12.0 & Young & Low & Early & Front & -45 & -5 \\
\hline & 26.1 & Young & Low & Mid & Front & -30 & 57 \\
\hline & 47.8 & Young & Low & Late & Front & -8 & 152 \\
\hline & 3.8 & Young & High & Early & Front & -54 & -41 \\
\hline & 9.2 & Young & High & Mid & Front & -48 & -17 \\
\hline & 20.8 & Young & High & Late & Front & -36 & 33 \\
\hline & 2.9 & Young & Low & Early & Hind & -55 & -45 \\
\hline & 7.1 & Young & Low & Mid & Hind & -50 & -27 \\
\hline & 16.5 & Young & Low & Late & Hind & -40 & 15 \\
\hline & 5.4 & Young & High & Late & Hind & -52 & -34 \\
\hline & 4.6 & Old & Low & Early & Front & -53 & -38 \\
\hline & 11.0 & Old & Low & Mid & Front & -46 & -10 \\
\hline & 24.2 & Old & Low & Late & Front & -32 & 48 \\
\hline & 3.4 & Old & High & Mid & Front & -54 & -43 \\
\hline & 8.4 & Old & High & Late & Front & -49 & -21 \\
\hline & 2.6 & Old & Low & Mid & Hind & -55 & -46 \\
\hline & 6.5 & Old & Low & Late & Hind & -51 & -29 \\
\hline
\end{tabular}

${ }^{1} \mathrm{PC}=$ Probability of cure.

${ }^{2}$ Parity: young $=$ first or second parity; old = third or higher parity.

${ }^{3} \mathrm{SCC}$ : low $=\operatorname{lnSCC}<6.9$; high $=\operatorname{lnSCC} 6.9$ or higher.

${ }^{4} \mathrm{LS}=$ Lactation stage: early $<100$ DIM; mid $100<$ DIM $\leq 200$; late $>200$ DIM.

${ }^{5} \mathrm{R}=$ Reproductive ratio.

for long periods should be considered for treatment. On the contrary, cows with induration of udder tissue, multiple infected quarters, or other indicators of very persistent infection should not be selected for treatment. Some treatment protocols explicitly exclude cows with palpable udder changes from antibiotic treatment (Deluyker et al., 2005). Thus, when a S. aureus control program is initiated, it may be necessary to implement a 3-pronged approach: 1) improve herd management, specifically milking routines; 2 ) identify cows that are not eligible for treatment and cull or segregate them (Wilson et al., 1995) or use early dry-off; and 3) treat cows that have a considerable chance of cure. Risk factors that predict the success of treatment have been identified in a number of countries and studies and are largely consistent across treatment and study protocols (Ziv and Storper, 1985; Sol et al., 1997, 2000; Deluyker et al., 2005). When the right cows, the right infections, and the right treatment duration are selected, the chance of cure after lactational treatment of persistent subclinical $S$. aureus mastitis can exceed $50 \%$. The sooner an infection is detected and treated, the higher the chance of cure. When a control program is first implemented, some existing infections will already be intractable, whereas extended treatment may be needed to cure others. Once the control program is in place, early detection and treatment of new infections is feasible and short-term treatment may be preferable from an economic perspective.

In herds with low risk of $S$. aureus transmission, treatment of an average cow with persistent subclinical $S$. aureus mastitis is not profitable. Three-day treatment can be profitable in such herds when cows are selected with an expected cure probability of approxi- 
Table 5. Sensitivity analysis of host, pathogen, and treatment factors on net benefit of 8-d treatment of subclinical Staphylococcus aureus mastitis during lactation on farms with low $(\mathrm{R}=0.32)$ or high risk of transmission $(\mathrm{R}=5.3)$.

\begin{tabular}{|c|c|c|c|c|c|c|c|}
\hline \multirow[b]{2}{*}{ Pathogen } & \multirow[b]{2}{*}{$\mathrm{PC}^{1}(\%)$} & \multicolumn{4}{|c|}{ Cow factors } & \multirow[b]{2}{*}{$\mathrm{R}^{5}=0.32$} & \multirow[b]{2}{*}{$\mathrm{R}=5.3$} \\
\hline & & Parity $^{2}$ & $\mathrm{SCC}^{3}$ & $\mathrm{DIM}^{4}$ & Quarter & & \\
\hline \multirow[t]{16}{*}{ Penicillin-sensitive } & 48.0 & Young & Low & Early & Front & -70 & 90 \\
\hline & 70.5 & Young & Low & Mid & Front & -47 & 188 \\
\hline & 86.1 & Young & Low & Late & Front & -30 & 257 \\
\hline & 20.9 & Young & High & Early & Front & -99 & -29 \\
\hline & 40.6 & Young & High & Mid & Front & -78 & 57 \\
\hline & 63.9 & Young & High & Late & Front & -54 & 159 \\
\hline & 16.7 & Young & Low & Early & Hind & -102 & -47 \\
\hline & 34.1 & Young & Low & Mid & Hind & -85 & 29 \\
\hline & 57.2 & Young & Low & Late & Hind & -61 & 130 \\
\hline & 27.7 & Young & High & Late & Hind & -91 & 1 \\
\hline & 24.4 & Old & Low & Early & Front & -95 & -13 \\
\hline & 45.5 & Old & Low & Mid & Front & -73 & 79 \\
\hline & 68.4 & Old & Low & Late & Front & -49 & 179 \\
\hline & 19.3 & Old & High & Mid & Front & -100 & -36 \\
\hline & 38.2 & Old & High & Late & Front & -80 & 47 \\
\hline & 31.9 & Old & Low & Late & Hind & -87 & 19 \\
\hline \multirow[t]{14}{*}{ Penicillin-resistant } & 36.1 & Young & Low & Early & Front & -83 & 38 \\
\hline & 59.4 & Young & Low & Mid & Front & -58 & 139 \\
\hline & 79.1 & Young & Low & Late & Front & -37 & 226 \\
\hline & 13.9 & Young & High & Early & Front & -106 & -59 \\
\hline & 29.5 & Young & High & Mid & Front & -89 & 9 \\
\hline & 52.0 & Young & High & Late & Front & -66 & 107 \\
\hline & 24.0 & Young & Low & Mid & Hind & -95 & -15 \\
\hline & 45.0 & Young & Low & Late & Hind & -73 & 77 \\
\hline & 19.0 & Young & High & Late & Hind & -100 & -35 \\
\hline & 16.5 & Old & Low & Early & Front & -103 & -48 \\
\hline & 33.8 & Old & Low & Mid & Front & -85 & 27 \\
\hline & 57.0 & Old & Low & Late & Front & -61 & 129 \\
\hline & 27.5 & Old & High & Late & Front & -92 & 0 \\
\hline & 22.3 & Old & Low & Late & Hind & -97 & -23 \\
\hline
\end{tabular}

${ }^{1} \mathrm{PC}=$ Probability of cure.

${ }^{2}$ Parity: young $=$ first or second parity; old $=$ third or higher parity.

${ }^{3} \mathrm{SCC}$ : low $=\operatorname{lnSCC}<6.9$; high $=\operatorname{lnSCC} 6.9$ or higher.

${ }^{4} \mathrm{LS}=$ Lactation stage: early $<100$ DIM; mid $100<$ DIM $\leq 200$; late $>200$ DIM.

${ }^{5} \mathrm{R}=$ Reproductive ratio.

mately $55 \%$ or higher (Table 4). For example, first- or second-parity cows infected in a front quarter with a PS strain, with cow-milk SCC $<1$ million cells $/ \mathrm{mL}$, and $>200$ DIM are eligible for treatment. Extended treatment is not profitable in low-transmission herds. Longer treatment will lead to a higher chance of cure but this benefit does not outweigh the higher costs of antibiotics and discarded milk. The interpretation of the economic benefit of treatment in low transmission herds is complicated by the fact that routine testing, potentially followed by lactational treatment of infected animals, is one of the factors that contributes to low risks of transmission (Smith et al., 1998; Zadoks et al., 2002a). In other words, the success of treatment leads to a reduction in exposure and contributes to a lowtransmission scenario. In the low-transmission situation, the economic benefit of treatment is subsequently limited. Routine testing of milk samples for SCC or mastitis pathogens also contributes to reduced trans- mission through increased awareness of the importance of udder health management (Hillerton et al., 1995; Zadoks et al., 2002a).

The biological and economic models presented in this paper have limitations, as do all models. Partial budgeting is a relatively simple method to calculate economic effects. It is useful in studies that compare relatively small changes in a system such as implementation of a test and cull (Goodger and Ferguson, 1987) or treatment program (Swinkels et al., 2005) vs. no implementation of a control program. The input variables of a partial budget model are fixed averages that are crude descriptors of reality. For example, the model does not take into consideration that there may be herdlevel constraints that limit the feasibility of treatment of culling of infected cows. In addition, the deterministic partial budget model allows culling or treatment of fractional cows or quarters. This problem can be addressed by use of a stochastic model, in which a whole cow 
or quarter is culled or treated and a random number generator is used to make this decision. A stochastic model also allows for estimation of the range of possible model outcomes, and for quantification of the likelihood of each outcome (Allore et al., 1998). Some events are unlikely to happen, but may have a very severe influence if they do happen, such as the outbreak of mastitis that resulted from the introduction of a novel $S$. aureus strain in the Washington State University herd (Smith et al., 1998). That outbreak shows that in addition to economic considerations, risk analysis may need to be part of herd management, including weighing of the likelihood of events, and the magnitude of potential consequences. A stochastic model can support riskbased decision-making. In addition to stochasticity or variability in input variables, there is uncertainty for many input variables in our model. The most important input variables in this study were bacteriological cure, probability of transmission, the duration of infection, the chance of culling due to subclinical mastitis, RPO, antibiotic costs, price of discarded milk, and costs of bacteriological culture (Table 3). When applying the economic model for on-farm treatment decisions, herdspecific values should be used for these economically important input variables whenever possible. If data on important input variables are scarce, further research on such topics is indicated. For example, $R$ is an important input variable in the economic model, but estimates of $R$ are scarce due the costly nature of studies needed to determine $\mathrm{R}$ or its components (Lam 1996; Zadoks et al., 2002a). A very crude estimate of $R$ can be obtained under field conditions based on the change in number of cows with elevated SCC. When $R=1$, each infected individual replaces itself on average with one new infected individual and the total number of infected individuals would not change. Thus, if the number of cows with elevated SCC increases, the crude estimate for $\mathrm{R}$ is greater than 1 . If the number of cows with elevated SCC decreases, the crude estimate for R is less than 1 . The number of infected cows at any point also depends on treatment and culling decisions and on the number of infections of environmental origin (Zadoks et al., 2002a).

The current model does not address potential interdependence of input variables. Interdependence of variables may exist at the herd level, the cow level, or the pathogen level. Cow level factors that affect multiple input parameters of the model include parity, milk production, and duration of infection. Younger animals have a higher probability of cure (Tables 4 and 5) as well as a higher RPO than older animals, due to a longer productive life expectancy. Table 3 shows that an increase in RPO is associated with higher net profit of lactational $S$. aureus treatment. Thus, both PC and
RPO favor treatment of young animals. The influence of milk production on economic benefit of treatment is more complex. High milk production increases the RPO of an animal (Houben et al., 1994) but high milk production is also associated with high losses due to discarded milk. Thus, high milk production contributes and detracts from the economic benefit of treatment. For an animal with high production potential (high RPO), treatment may only be cost-effective in late lactation when the actual yield and loss due to discarded milk are low, and the expected benefits are high due to the higher PC associated with DIM > 200. Early treatment, which requires early detection, is beneficial at the herd level and cow level. Compared with late detection of infection, detection of infection in its early stages is associated with lower average SCC (higher chance of cure), lower number of infected quarters (lower cost of culture and sensitivity testing; fewer quarters that need to cure), and longer prevented duration of infection (more prevented costs). All factors favor treatment of infections that are detected early after onset. For cows that are in early lactation, these benefits may outweigh the disadvantage that early-lactation animals have compared with late-lactation animals in terms of PC. In other words, the economic loss associated with treatment in early lactation may be smaller than the economic loss associated with postponement of such treatment until late lactation. Currently, little is known about correlations among strain characteristics that may affect the net benefit of treatment. Several studies have shown that $S$. aureus strains may differ in their ability to cause intramammary infections (Zadoks et al., 2002b), clinical mastitis (Zadoks et al., 2000), or mastitis outbreaks (Smith et al., 1998). The majority of $S$. aureus infections on multiple continents are caused by a limited number of cow- and udder-adapted strains, as recently shown by multilocus sequence typing (Smith et al., 2005). It is conceivable that udderadapted strains show a higher probability of transmission and a lower chance of cure than strains that are not adapted to this specific niche. In that case, a strain might be associated with low PC, which would not favor treatment, and high $\mathrm{R}$, which, by contrast, would increase the economic benefit of treatment.

Despite its limitations, this model is the best available estimate of the net cost or benefit of lactational treatment of subclinical $S$. aureus mastitis. The model may underestimate treatment benefits, because we assumed the costs of penalties for antibiotic residues or high SCC in bulk tank milk and costs of impaired fertility due to mastitis to be zero. If such costs were included in the model, the net profit of treatment vs. no treatment would increase. In addition, we assumed that milk with antibiotic residues is discarded. In the Nether- 
lands, feeding of waste milk is discouraged to prevent transmission of diseases such as Johne's disease or salmonellosis to calves. In reality, the majority of farmers do not discard milk with antibiotic residues. Waste milk is fed to calves to reduce short-term costs by saving milk replacer, and potential costs of extra disease in the long term are ignored. If we had assumed that discarded milk was fed to calves and that milk replacer and discarded milk have the same value, there would be no net reduced revenue associated with milk withholding. In this situation, the profitability of treatment would increase by $€ 21.25$ for 3 -d treatment and by $€$ 38.96 for 8 -d treatment (Table 2). This would make treatment of subclinical $S$. aureus mastitis more attractive economically, at least in the short term.

The partial budget presented in this paper is based on economic and regulatory conditions in the Netherlands, which are very different from those in countries outside the European Union. For example, cost of labor was assumed to be zero in the Dutch model because most farms in the Netherlands are family-owned and operated. Average herd size in the Netherlands is 65 cows. In the northeastern United States, some farms have similar size, ownership, and management. By contrast, large dairy farms in the United States use hired labor for which cost cannot be set at zero. The cost of labor would decrease the benefit of $S$. aureus treatment. In the United States and Canada, a quota system is not in place so that the value of lost milk production is higher than in the Dutch situation. The higher value of lost milk production associated with high SCC in infected animals would increase the calculated prevented losses and hence the benefit of treatment. Feeding waste milk to calves is common practice in the United States and would decrease losses associated with treatment such that the benefit of treatment would increase compared with our estimates. The cost of bacterial culture in New York State is similar to the cost of bacterial culture in the Netherlands, but culture in New York State does not routinely include PS testing. Milk prices differ by country and region and are much higher in the European Union than in some other countries, e.g., Australia and New Zealand. Average feed costs and milk yields differ between countries and breeds. Clearly, the estimates from our model do not apply to all dairy systems. However, our model is an example of a rational approach to decision-making based on scientific knowledge of infection biology and economic considerations. Profit margins in the dairy industry are decreasing. As a result, economic considerations will become increasingly important in decisionmaking. Decision-making based on economic criteria requires a shift in attitude for many producers and veterinarians who have traditionally based decisions on expectations with respect to bacteriological cure or even on emotional considerations. Producers, veterinarians, and herd consultants should shift from the current focus on a high probability of treatment success for individual cows as determined by bacteriological cure to economic consequences of treatment of specific cows on a specific farm.

The current economic model does not cover potential negative side effects of lactational treatment. When use of antibiotics for treatment of subclinical infections is promoted, increased use of antibiotics and an associated risk of increased antimicrobial resistance in $S$. aureus would be anticipated. However, if treatment of subclinical mastitis prevents clinical mastitis and transmission of $S$. aureus to other cows, use of antimicrobials for treatment of subclinical infections may result in a net reduction in antimicrobial usage in the long term. Even when antibiotic usage is not decreased, it is difficult to predict how antimicrobial usage will affect the prevalence of antimicrobial resistance. Penicillin-based antibiotics have been used widely for decades, and in many studies, a decrease in penicillin resistance among $S$. aureus rather than an increase has been documented in the past decade (Erskine et al., 2002; Sol, 2002; Makovec and Ruegg, 2003). Thus, field data do not justify rejection of antibiotic treatment of subclinical infections based solely on the fear of a potential impact on resistance. The impact of treatment on antimicrobial resistance in S. aureus should be monitored, irrespective of the treatment indication (subclinical mastitis, clinical mastitis, dry cow treatment), as has been done and continues to be done in many countries.

\section{CONCLUSIONS}

The economic benefit of antibiotic treatment of subclinical mastitis caused by $S$. aureus is dependent on local economic conditions and on host, pathogen, and management factors. On farms where transmission of $S$. aureus is likely, antibiotic treatment of cows with subclinical $S$. aureus mastitis is often profitable, if the right cows are selected for treatment using known risk factors for cure. On farms where contagious transmission is unlikely, extended treatment is nearly always uneconomical, but 3-d antibiotic treatment can be economically profitable, especially for young animals with recent infections with penicillin-sensitive strains of S. aureus.

\section{REFERENCES}

Allore, H. G., H. N. Erb, L. W. Schruben, and P. A. Oltenacu. 1998. A simulation of strategies to lower bulk tank somatic cell count below 500,000 per milliliter. J. Dairy Sci. 81:694-702.

Barkema, H. W., Y. H. Schukken, T. J. G. M. Lam, M. L. Beiboer, G. Benedictus, and A. Brand. 1998. Management practices associ- 
ated with low, medium, and high somatic cell counts in bulk milk. J. Dairy Sci. 81:1917-1927.

Beaudeau, F., A. Henken, C. Fourichon, K. Frankena, and H. Seegers. 1993. Associations between health disorders and culling of dairy cows: A review. Livest. Prod. Sci. 35:213-231.

Bramley, A. J., and F. H. Dodd. 1984. Reviews of the progress of dairy science: Mastitis control—Progress and prospects. J. Dairy Res. 51:481-512.

Deluyker, H. A., S. N. Van Oye, and J. F. Boucher. 2005. Factors affecting cure and somatic cell count after pirlimycin treatment of subclinical mastitis in lactating cows. J. Dairy Sci. 88:604-614.

De Vos, C. J., and A. A. Dijkhuizen. 1998. [Economical aspects of udder health]. Pages 7-9 in Proceedings wetenschappelijke vergadering van de Groep geneeskunde van het rund Rheden. Dutch Assoc. Bovine Pract., Utrecht, The Netherlands. [In Dutch].

Eberhart, R. J., L. J. Hutchinson, and S. B. Spencer. 1982. Relationships of bulk tank somatic cell counts to prevalence of intramammary infection to indices of herd production. J. Food Prot. 45:1125-1128.

Erskine, R. J., R. D. Walker, C. A. Bolin, P. C. Bartlett, and D. G. White. 2002. Trends in antibacterial susceptability of mastitis pathogens during a seven-year period. J. Dairy Sci. 85:1111-1118.

Esslemont, R. J., and M. A. Kossaibati. 1997. Culling in 50 dairy herds in England. Vet. Rec. 140:36-39.

Fox, L. K., and J. M. Gay. 1993. Contagious mastitis. Vet. Clin. North Am. Food Anim. Pract. 9:475-487.

Goodger, W. J., and G. Ferguson. 1987. Benefits and costs of a control program for an epizootic of Staphylococcus aureus mastitis. JAVMA 190:1284-1287.

Hillerton, J. E., A. J. Bramley, R. T. Staker, and C. H. McKinnon. 1995. Patterns of intramammary infection and clinical mastitis over a 5 year period in a closely monitored herd applying mastitis control measures. J. Dairy Res. 62:39-50.

Hortet, P., and H. Seegers. 1998. Calculated milk production losses associated with elevated somatic cell counts in dairy cows: Review and critical discussion. Vet. Res. 29:497-510.

Houben, E. H., R. B. Huirne, A. A. Dijkhuizen, and A. R. Kristensen. 1994. Optimal replacement of mastitic cows determined by a hierarchic Markov process. J. Dairy Sci. 77:2975-2993.

Lam, T. J. G. M. 1996. Dynamics of bovine mastitis: A field study in low somatic cell count herds. Ph.D. Dissertation, Utrecht University, The Netherlands.

Lam, T. J. G. M., M. C. DeJong, Y. H. Schukken, and A. Brand. 1996. Mathematical modeling to estimate efficacy of postmilking teat disinfection in split-udder trials of dairy cows. J. Dairy Sci. 79:62-70.

Lam, T. J. G. M., J. H. van Vliet, Y. H. Schukken, F. J. Grommers, A. van Velden-Russcher, H. W. Barkema, and A. Brand. 1997. The effect of discontinuation of postmilking teat disinfection in low somatic cell count herds. Dynamics of intramammary infections. Vet. Q. 19:47-53.

Makovec, J. A., and P. L. Ruegg. 2003. Results of milk samples submitted for microbiological examination in Wisconsin from 1994 to 2001. J. Dairy Sci. 86:3466-3472.

McDermott, M. P., H. N. Erb, R. P. Natzke, F. D. Barnes, and D. Bray. 1983. Cost benefit analysis of lactation therapy with somatic cell counts as indications for treatment. J. Dairy Sci. 66:11981203.

NRS (Nederlands Rundvee Syndicaat). 2003-2004. Annual Statistics. CR-Delta, Arnhem, The Netherlands.

Poelarends, J. J., H. Hogeveen, O. C. Sampimon, and J. Sol. 2001. Monitoring subclinical mastitis in Dutch dairy herds. Page 145149 in Proc. 2nd Int. Symp. Mastitis and Milk Quality, Vancouver, BC. National Mastitis Council, Inc., Madison, WI.
Schrick, F. N., M. E. Hockett, A. M. Saxton, M. J. Lewis, H. H. Dowlen, and S. P. Oliver. 2001. Influence of subclinical mastitis during early lactation on reproductive parameters. J. Dairy Sci. 84:1407-1412.

Seegers, H., F. Beaudeau, C. Fourichon, and N. Bareille. 1998. Reasons for culling in French Holstein cows. Prev. Vet. Med. $36: 257-271$.

Smolders, F. J. 1994. Fertility and production, important culling reasons. Praktijkonderzoek 1:20-22. [In Dutch]

Smith, E. J., L. E. Green, G. F. Medley, H. E. Bird, L. K. Fox, Y. H. Schukken, J. V. Kruze, A. J. Bradley, R. N. Zadoks, and C. G. Dowson. 2005. Multilocus sequence typing of intercontinental Staphylococcus aureus isolates. J. Clin. Microbiol. 43:4737-4743.

Smith, T. H., L. K. Fox, and J. R. Middleton. 1998. Outbreak of mastitis caused by one strain of Staphylococcus aureus in a closed dairy herd. JAVMA 212:553-556.

Sol, J. 2002. Cure of Staphylococcus aureus mastitis in Dutch dairy cows. Ph.D. Dissertation, Utrecht University, The Netherlands.

Sol, J., O. C. Sampimon, H. W. Barkema, and Y. H. Schukken. 2000. Factors associated with cure after therapy of clinical mastitis caused by Staphylococcus aureus. J. Dairy Sci. 83:278-284.

Sol, J., O. C. Sampimon, J. J. Snoep, and Y. H. Schukken. 1997. Factors associated with bacteriological cure during lactation after therapy for subclinical mastitis caused by Staphylococcus aureus. J. Dairy Sci. 80:2803-2808.

St. Rose, S. G., J. M. Swinkels, W. D. Kremer, C. L. Kruitwagen, and R. N. Zadoks. 2003. Effect of penethamate hydriodide treatment on bacteriological cure, somatic cell count and milk production of cows and quarters with chronic subclinical Streptococcus uberis or Streptococcus dysgalactiae infection. J. Dairy Res. 70:387-394.

Swinkels, J. M., J. G. A. Rooijendijk, R. N. Zadoks, and H. Hogeveen. 2005. Use of partial budgeting to determine the economic benefits of antibiotic treatment of chronic subclinical mastitis caused by Streptococcus uberis and Streptococcus dysgalactiae. J. Dairy Res. 72:75-85.

Whitaker, D. A., J. M. Kelly, and S. Smith. 2000. Disposal and disease rates in 340 British dairy herds. Vet. Rec. 146:363-367.

Wilson, D. J., R. N. Gonzalez, and P. M. Sears. 1995. Segregation or use of separate milking units for cows infected with Staphylococcus aureus: Effects on prevalence of infection and bulk tank somatic cell count. J. Dairy Sci. 78:2083-2085.

Yamagata, M., W. J. Goodger, L. Weaver, and C. Franti. 1987. The economic benefit of treating subclinical Streptococcus agalactiae mastitis in lactating cows. JAVMA 191:1556-1561.

Zadoks, R. N., H. G. Allore, T. J. Hagenaars, H. W. Barkema, and Y. H. Schukken. 2002a. A mathematical model of Staphylococcus aureus control in dairy herds. Epidemiol. Infect. 129:397-416.

Zadoks, R. N., W. van Leeuwen, H. W. Barkema, O. C. Sampimon, H. Verbrugh, Y. H. Schukken, and A. van Belkum. 2000. Application of pulsed-field gel electrophoresis and binary typing as tools in veterinary clinical microbiology and molecular epidemiologic analysis of bovine and human Staphylococcus aureus isolates. J. Clin. Microbiol. 38:1931-1939.

Zadoks, R. N., W. B. van Leeuwen, D. Kreft, L. K. Fox, H. W. Barkema, Y. H. Schukken, and A. van Belkum. 2002b. Comparison of Staphylococcus aureus isolates from bovine and human skin, milking equipment, and bovine milk by phage typing, pulsed-field gel electrophoresis, and binary typing. J. Clin. Microbiol. 40:38943902.

Zepeda, L., K. L. Buelow, K. V. Nordlund, C. B. Thomas, M. T. Collins, and W. J. Goodger. 1998. A linear programming assessment of the profit from strategies to reduce the prevalence of Staphylococcus aureus mastitis. Prev. Vet. Med. 33:183-193.

Ziv, G., and M. Storper. 1985. Intramuscular treatment of subclinical staphylococcal mastitis in lactating cows with penicillin G, methicillin and their esters. J. Vet. Pharmacol. Ther. 8:276-283. 